Bernard Hoekman is the policy and research manager of the international trade group at the World Bank, as well as a research fellow at the Center for Economic Policy Research. Thanks are due to Wendy Dobson, Carsten Fink, Jeffrey Schott, Aaditya Mattoo, T.N. Srinivasan, and Robert Stern for helpful comments, Isidro Soloaga and Soraphol Tulayasathien for help with data processing, and Simeon Djankov and Francis Ng for providing data. The views expressed are those of the author and should not be attributed to the World Bank.

\section{The Next Round of Services Negotiations: Identifying Priorities and Options}

\section{Bernard Hoekman}

\section{INTRODUCTION}

T he agreement to create a General Agreement on Trade in Services (GATS) was one of the major innovations to emerge from the Uruguay round. Trade in services was not covered by the 1947 General Agreement on Tariffs and Trade (GATT), even though such trade had always accounted for a non-trivial share of the foreign exchange earnings (expenditures) of many countries. The best estimates available suggest global trade in servicesdefined to include sales of services by affiliates of multinationals-stood at $\$ 2.2$ trillion in 1997 (Table 1). Clearly this is not a nontraded sector.

Given the novelty of the subject for trade officials, it was not surprising that most of the efforts expended during the Uruguay Round negotiations on services centered on conceptual and "architectural" issues-how to define trade, what rules and principles should apply to measures affecting this trade, and devising mechanisms to determine the coverage of the agreement. No liberalization of trade in services occurred during the Uruguay Round. Instead, what emerged was a framework under which liberalization could be pursued in the future, with explicit commitments to engage in further negotiations to liberalize trade in services five years after the entry into force of the GATS, and periodically, thereafter. Thus, new negotiations on services were launched in 2000.

Although post-Uruguay Round sectoral negotiations to expand the coverage of GATS in the areas of basic telecommunication and financial services attracted a significant amount of media attention, the GATS, itself, has not generated a lot of public interest. Its provisions, let alone its existence, remain relatively unknown or understood even among those who have an interest in the functioning of the trading system. No major disputes regarding the implementation of the agreement have been brought forward, no doubt reflecting, in part, that no liberalization was achieved. This suggests the agreement is not perceived as particularly relevant to the various stakeholders, in particular, multinational business. Indeed, in the run up to the coming negotiations, services industries have made it clear that substantial efforts are required to make the GATS more relevant to the needs of business, in particular, as a tool for enhancing market access conditions. ${ }^{1}$ There is wide recognition among both the business community and government officials that the status quo is not an acceptable option, simply because the existing schedules of commitments in the GATS are not particularly useful. The correspondence between what is scheduled and the effective barriers to trade and investment that are in force is rather loose, to say the least. The question of how to proceed on services is particularly acute for developing countries. Almost all governments increasingly recognize the vital role that an efficient and vibrant service industry plays in the process of economic and social development. That is, certain services are basic inputs or components of the economic infrastructure, whereas other services can be a provisional shelter useful for social stability.

In principle, the task confronting World Trade Organization (WTO) members in the area of services appears straightforward: to achieve a significant degree of liberalization and "lock-in" through scheduling commitments in the GATS. Realization of this objective will require governments to identify where domestic liberalization and policy reform would be beneficial from an economic development and growth perspective. Multilateral liberalization of trade in services will be more difficult to achieve than in the case of merchandise trade, as the characteristics of services and the policies restricting trade in services lend themselves less readily to the method of reciprocal exchange of market access

\footnotetext{
${ }^{1}$ The U.S. Coalition of Services Industries (CSI) has been in the vanguard, organizing a World Services Congress a month before the late November 1999 Ministerial meeting that was expected to launch a new round, as well as a number of preparatory public-private sector meetings in various parts of the world.
} 
Table 1

\section{International Transactions Services by Modes of Supply, 1997}

\begin{tabular}{|c|c|c|c|}
\hline $\begin{array}{l}\text { GATS Mode } \\
\text { of Supply }\end{array}$ & Category & $\begin{array}{c}\text { Value } \\
\text { (\$ billion) }\end{array}$ & $\begin{array}{c}\text { Cumulative Share } \\
\text { (percent) }\end{array}$ \\
\hline Mode 1 & $\begin{array}{l}\text { Commercial services } \\
\text { (excl. travel) }\end{array}$ & 890 & 41.0 \\
\hline Mode 2 & Travel & 430 & 19.8 \\
\hline Mode 3 & $\begin{array}{l}\text { Gross output } \\
\text { of foreign affiliates }\end{array}$ & 820 & 37.8 \\
\hline Mode 4 & $\begin{array}{l}\text { Compensation } \\
\text { of employees }\end{array}$ & 30 & 1.4 \\
\hline Total & & 2,170 & 100.0 \\
\hline
\end{tabular}

NOTE: Modes 1, 2, and 4 are derived from balance-of-payments data.

SOURCE: Karsenty (2000).

"concessions." The challenge, therefore, is to develop negotiation modalities that will encourage governments to use the GATS as a mechanism through which to pursue desired domestic reforms. This is a nontrivial challenge. The recent experience of regional economic integration agreements that cover services trade in Latin America illustrates that achieving liberalization by means of international agreements is difficult: to date very little has been achieved (World Bank, 2000). ${ }^{2}$

This paper discusses what might be negotiated in the GATS and the WTO to promote liberalization of services markets. After briefly recalling the possible rationales for engaging in multilateral trade negotiations and international cooperation, the paper reviews available information on - and analysis of - services trade and trade barriers. The discussion then turns to options for making the GATS a more relevant instrument of regulatory reform and market access, and ends with some concluding remarks.

\section{WHY NEGOTIATE? POTENTIAL GAINS FROM COOPERATION}

Many governments around the world have been engaging in a process of economic reform that is, at least partially, informed by the insight that policy should be neutral in terms of creating incentives to invest in particular activities. Rather than tolerate monopolies in sectors traditionally seen as natural monopolies (e.g., telecoms, rail transport, ports), reforms have focused on encouraging competition. Depending on local circumstances and political constellations, governments may face more or less opposition to reforms that aim to increase competition in services markets. Although often supported by the manufacturing sector, which has an interest in having access to a wide array of efficiently produced services inputs, final consumers may oppose liberalization because of concerns about a reduction in the frequency or geographical coverage of services, such as in telecoms and transport, and increases in market prices as subsidies are eliminated. Labor unions may be concerned about the potential for large-scale layoffs, and those in society who have benefited from subsidized access to services may resist a change in the status quo that is expected to raise prices or restrict supply.

Thus, governments may be constrained in implementing reforms that would benefit society at large because of the opposition of politically powerful, vested interests. If so, international trade agreements offer a potential way for breaking domestic deadlocks by mobilizing groups to support reform. The traditional raison d'etre of the GATT is that groups that would benefit from better access to export markets are induced to throw their weight behind import liberalization. Analogous reasoning applies in the services context, with the difference that for many countries, export interests in services may be weaker than in manufacturing or agriculture because services are more difficult to trade. If so, there is greater need to mobilize support from exporters of real goods that require access to competitively priced and high-quality service inputs if they are to be able to contest global markets. This, in turn, puts a high premium on the availability of information and analysis of the economic impact of status quo services policies. However, given that foreign direct investment (FDI) is a significant mode of supplying non-tradable services, potential direct investors may have a strong export interest and supply the traditional political economy dynamics that have driven the GATT talks.

In addition to potentially assisting in changing the political economy of reform, international agree-

\footnotetext{
${ }^{2}$ However, there have been a few integration agreements that have managed to achieve progressive liberalization. Abstracting from the special case of the European Communities, the primary example is the Closer Economic Relations (CER) agreement between Australia and New Zealand.
} 
ments also can help provide focal points for regulatory reform and provide templates for domestic policy measures that are welfare enhancing, such as support for the implementation of pro-competitive regulatory regimes. This is particularly important in the case of network-type services, such as in financial or telecom services, where there is a need to deal with problems of asymmetric information or to ensure universal service. One of the beneficial "didactic" outcomes of the negotiations on financial services was that it helped educate decision makers on the importance of distinguishing between liberalization and (de) regulation. Liberalization involves the elimination of discrimination in the treatment of foreign and national services providers and removal of market access barriers-to both cross-border provision and establishment. But, this does not restrict the government's ability to enforce regulatory regimes, undertake prudential supervision, conduct monetary policy, or manage external capital flows (Key, 1997). ${ }^{3}$ The same applies to other sectors. In all cases, however, the required regulatory capacity must be there, if needed. In principle, multilateral negotiations can help by identifying good regulatory practices and principles that governments should consider adopting, as well as criteria or necessary conditions that must be met before certain reforms should be undertaken. ${ }^{4}$

Finally, an important potential beneficial role that multilateral agreements can play is to enhance the credibility of a government's economic policy stance. This can be very important for countries where there is a history of policy reversal. The GATS offers a mechanism for governments to precommit to a reform path, by spelling out what will be done over a period of time, as well as lock-in reforms that have already been achieved. A number of governments used the Agreement on Basic Telecommunications as a precommitment device-probably the most constructive use that has been made of the GATS to date by WTO members. Clearly the strength of the enforcement mechanisms that can be invoked plays an important role in determining the "credibility impact" of multilateral commitments. Although the WTO has one of the strongest and most effective enforcement mechanisms of any international agreement, one of the problems that it confronts is that it relies excessively on export interests to contest violations of an agreement. This can greatly reduce the "credibility payoff" for small countries, as exporters in large nations may have little interest in "suing" such countries (Hoekman and Mavroidis, 2000).

\section{WHAT IS AT STAKE? IDENTIFYING THE BARRIERS AND THE GAINS FROM COOPERATION}

To participate effectively and maximize the benefits of GATS negotiations, it is vital that governments have a well-defined domestic reform agenda they desire to pursue. They also must know what the major barriers to their exports are. Ideally, governments should use multilateral negotiations to pursue domestic reforms that are desired in any event, seeking better access to export markets in the process. A major problem confronting governments is the determination of priorities - both for domestic reform and regarding foreign market access barriers. Without good information on what policies - at home and abroad-are most detrimental to economic growth and export development, a government cannot maximize the benefits of participating in a multilateral negotiation.

In principle, a general equilibrium approach is required to identify which domestic sectors deserve priority attention and determine the overall impact of status-quo policies and possible reforms. This is non-trivial, as the need extends beyond considering the interactions between the various sectors of the economy to a general equilibrium assessment of policies to identify regulatory reforms required as a consequence of liberalization initiatives. The absence of an economy-wide framework often results in highly non-uniform patterns of protection for industries that are detrimental to the long-term growth prospects of the economy. An illustration is provided by the emerging markets that were embroiled in financial crisis in the late 1990s. The banking crisis in Asia, in part, was the result of one sector, banking, remaining highly protected and badly regulated during a period in which substitute services in the form of short-term capital flows were being liberalized and the electronic "transportation" costs of moving these funds were declining rapidly (Hoekman and Messerlin, 2000). The problem is in ensuring that such situations do not occur. Information and analysis must play a major role in this regard.

\footnotetext{
${ }^{3}$ In the financial services context, terminological confusion can easily occur. For example, capital account liberalization removes capital controls and restrictions on the convertibility of the currency, but is not the same as financial services liberalization.

${ }^{4}$ For example, it makes no sense to allow foreign takeovers of incumbents in sectors where there is a ban on new entry, and where there is only a weak or nonexistent competition authority to control the behavior of firms. In such cases liberalization is unlikely to be welfare maximizing.
} 
Table 2

Top 15 Service Trading Countries And Economies With The Highest

Relative Specialization In Cross-Border Services, 1997

\begin{tabular}{lcc|lcc|lc}
\hline Importers: & $\begin{array}{c}\text { Share } \\
\text { (percent) }\end{array}$ & $\begin{array}{c}\text { Cumulative } \\
\text { Share } \\
\text { (percent) }\end{array}$ & Exporters: & $\begin{array}{c}\text { Share } \\
\text { (percent) }\end{array}$ & $\begin{array}{c}\text { Cumulative } \\
\text { Share } \\
\text { (percent) }\end{array}$ & $\begin{array}{l}\text { Countries with Highest } \\
\text { Revealed Comparative } \\
\text { Advantage }\end{array}$ \\
United States & 11.1 & 11 & United States & 16.7 & 17 & Kiribati \\
Japan & 9.9 & 21 & UK & 7.8 & 25 & Nepal & Mozambique \\
Germany & 8.0 & 29 & Japan & 7.2 & 32 & Neth. Antilles \\
Italy & 5.9 & 35 & Germany & 6.6 & 38 & 53 \\
France & 5.1 & 40 & France & 5.9 & 44 & Cape Verde \\
UK & 4.8 & 45 & Netherlands & 4.8 & 49 & Greece \\
Netherlands & 3.7 & 49 & Italy & 4.7 & 54 & Egypt \\
Canada & 2.7 & 51 & Belgium & 3.2 & 57 & Djibouti \\
Belgium & 2.6 & 54 & Hong Kong & 3.0 & 60 & Ethiopia \\
Korea & 2.4 & 56 & Singapore & 2.7 & 63 & Philippines \\
China & 2.2 & 58 & Korea & 2.3 & 65 & Vanuatu \\
Spain & 2.2 & 61 & Canada & 2.3 & 67 & Latvia \\
Taiwan & 1.8 & 62 & Switzerland & 2.0 & 69 & Samoa \\
Malaysia & 1.7 & 64 & Spain & 1.9 & 71 & Jordan \\
Austria & 1.6 & 66 & Austria & 1.7 & 73 & Antigua and Barbuda \\
\hline
\end{tabular}

NOTE: The revealed comparative advantage (RCA) of country $i$ for product $j$ is measured by the item's share in the country's exports relative to its share in world trade. That is, if $x_{i j}$ is the value of country $i$ 's exports of $j$, and $X_{t j}$ is the country's total exports, its revealed comparative advantage index is: $R C A_{i j}=\left(\mathrm{x}_{i j} / \mathrm{X}_{t j}\right) \div\left(\mathrm{X}_{i w} / \mathrm{X}_{t w}\right)$.

SOURCE: Karsenty (2000).

From a negotiation perspective, care must be taken not to commit to an inappropriate sequencing of reforms, or an outcome that is unbalanced in the sense of neglecting important complementary activities or sectors.

The need to consider regulatory reform (be it deregulation or strengthening of regulatory oversight) is especially prominent in the context of services to ensure that the binding constraints on entry and competition are relaxed. Of particular importance for trade in services is the impact of-and rationale for-restrictions on inward FDI, both entry (ownership) limitations and operating requirements. Despite the worldwide liberalization of FDI that has occurred in the last decade, policies often remain restrictive, especially as regards equity (ownership) limits. Theoretical work has begun to emerge exploring the potential effects of FDI restrictions on services. This research strongly supports the conventional wisdom that FDI is beneficial to host economies-not only because it is a source of new knowledge and competitive pressure, but also because FDI in services can increase the demand for skilled workers and help host countries to begin to produce and export advanced products (Markusen, Rutherford, and Tarr, 1999). This work suggests that the rationale for ownership restrictions may be weak if it has the effect of inhibiting entry.

It is crucial to identify and consider the rationales for policies that limit competition in services. A fullfledged computable general equilibrium (CGE) approach is often impossible given resource constraints and the absence of data at the detailed sectoral level. It may be more productive to define a "cluster" approach that groups sets of interdependent activities together and focuses on the policies that affect the efficiency of the various elements of the cluster. Inputoutput tables and social accounting matrices can be used to determine the various clusters of activities and their major inputs. But, they must be complemented by surveys of the businesses producing and 
using the services involved to identify the main policies that restrict competition. Such an approach could be used in the GATS context to identify the bundle of activities and policies on which commitments should be sought or made. For example, making a marketaccess commitment for hotels with a view to encouraging tourism-related investment may have little effect if there are restrictions on air transport to or zoning regulations in favored areas that prevent new entry. Similar considerations apply to multimodal transport, express courier services, and value-added information services. While obvious, and generally an approach that is followed in domestic policy-making, the "cluster" approach does not appear to be employed at the multilateral negotiating level (Hoekman and Messerlin, 2000).

It also is important to identify and reduce the major barriers maintained by potential trading partners that restrict exports, temporary entry of services providers, and/or outward FDI. Developing countries have a large stake in being able to contest foreign services markets. Although the large Organization for Economic Cooperation and Development (OECD) countries dominate global trade in services, developing countries dominate the list of countries that are most specialized in (dependent on) services exports as a source of foreign exchange (Table 2). In most instances this reflects the importance of tourism and/ or transportation services. But, developing countries also have become large exporters of transactions processing, back-office services (Jamaica) or information and software development services (India). The potential to exploit recent and emerging technological developments-such as E-commerce-that allow cross-border trade in services and provide firms with incentives to slice up the value chain geographically is enormous (UNCTAD and World Bank, 1994; Hoekman and Primo Braga, 1997).

Relatively little information is available on the barriers that restrict international trade in services. Governments and negotiators ran into this constraint during the Uruguay Round, and some progress has been made since then in improving the database for negotiations. Most effort has gone into better measurement of stocks and flows, and advances have been made, especially in developed countries (Karsenty, 2000; Whichard, 1999). Much less has been done on the policy side. In large part, this reflects the immense difficulty of identifying and quantifying barriers to services trade. These difficulties are well known and will not be elaborated here. A major problem with the GATS is that the positive list approach to scheduling commitments does not generate comprehensive and economically meaningful data on the measures that are imposed by countries. Absent a careful and comprehensive sector-by-sector assessment on a country-by-country basis, the only way to get a handle on the relative magnitude of barriers to trade in services is through indirect methods. Various approaches are possible, and efforts have recently been made to use some of these.

One is to build on recent improvements in trade and FDI flow data to construct measures of "revealed" openness. That is, the pattern of bilateral trade can be compared with a measure of what trade should be. A first attempt to do this has been undertaken by Francois and Hoekman (1999), who fit a gravity model to bilateral trade in services flows between the United States and its partner countries to estimate tariff equivalents for each partner country's or region's barriers to trade in services. The results for business/finance and construction services are reported in Table 3. Assuming Hong Kong and Singapore are appropriate "free trade" benchmarks, the estimates for business/financial services suggest that although average services barriers are often above applied average tariffs on manufactures, in many countries services barriers are not very high. Indeed, in some cases the average merchandise tariff is significantly greater than the estimated services tariff equivalent (South and Southeast Asia, Middle East, and North Africa). The highest services tariff equivalent estimate is 36 percent (for Brazil). Japan, China, Turkey, and South Asia follow with 20 percent rates. All in all, the trade-based estimates suggest barriers to trade in business services may not be very large.

This is not the case for construction, the other service sector for which there is detailed bilateral trade data for the United States. Here we see much higher barrier estimates, as would be expected given the resistance in most countries to allowing foreign construction firms to bid for procurement contracts and existing barriers to movement of semiskilled workers. Tariff equivalent estimates are in the 40-60 percent range for China, South Asia, Brazil, Turkey, Central Europe, Russia, and South Africa. For OECD countries they are lower, but still significant, in the 10-30 percent range. Clearly, these estimates are sensitive to a variety of factors, not least of which is the treatment of U.S. firms as opposed to firms from other countries in this sector. Low construction tariff equivalent estimates for North America presumably reflect in part the operation of North American Free Trade Agreement (NAFTA), whereas the low numbers 
Table 3

Estimated Tariff Equivalents In Traded Services: Gravity-Model Based Regression Method (Percent)

\begin{tabular}{|c|c|c|c|}
\hline Countries/Regions: & $\begin{array}{c}\text { Average Tariff on } \\
\text { Merchandise* }\end{array}$ & Business/Construction & Financial Services \\
\hline North America ${ }^{+}$ & 6.0 & 8.2 & 9.8 \\
\hline Western Europe & 6.0 & 8.5 & 18.3 \\
\hline Australia and New Zealand & 5.0 & 6.9 & 24.4 \\
\hline Japan & 6.0 & 19.7 & 29.7 \\
\hline China & 18.0 & 18.8 & 40.9 \\
\hline Taiwan & n.a. & 2.6 & 5.3 \\
\hline Other NICs & n.a. & 2.1 & 10.3 \\
\hline Indonesia & 13.0 & 6.8 & 9.6 \\
\hline Other South East Asia & 10.0 & 5.0 & 17.7 \\
\hline India & 30.0 & 13.1 & 61.6 \\
\hline Other South Asia ** & 25.0 & 20.4 & 46.3 \\
\hline Brazil & 15.0 & 35.7 & 57.2 \\
\hline Other Latin America & 12.0 & 4.7 & 26.0 \\
\hline Turkey ** & 13.0 & 20.4 & 46.3 \\
\hline Middle East and North Africa & 20.0 & 4.0 & 9.5 \\
\hline CEECs + Russia & 10.0 & 18.4 & 51.9 \\
\hline South Africa & 6.0 & 15.7 & 42.1 \\
\hline Other Sub-Saharan Africa & n.a. & 0.3 & 11.1 \\
\hline Rest of World & n.a. & 20.4 & 46.3 \\
\hline
\end{tabular}

NOTE: The basic methodology is to estimate a gravity equation vis-à-vis U.S. trade, using exports as the dependent variable and percapita income, GDP, and a dummy for Western Hemisphere countries as regressors. Hong Kong and Singapore are considered to be free trade "benchmarks" in the regressions, and deviations from predicted imports, relative to this free trade benchmark, are taken as an indication of barriers to trade. These are backed out from a constant elasticity import demand function as follows: T1/TO $=(M 1 / M 0) \mathrm{x}$ $(1 / \varepsilon)$, where $T 1$ is the power of the tariff equivalent, and $M 1 / M O$ is the ratio of actual to predicted imports (normalized relative to the free trade benchmark ratio for Hong Kong and Singapore), and $\varepsilon$ is the demand elasticity (assumed to be -4 ).

* Tariff averages are unweighted across all commodities and for the latest available year, in many cases 1997 or 1998 . Country coverage of regions is not comprehensive. Reported figures should be regarded as indicative of the prevailing order of magnitude only.

* Turkey and Other South Asia are not available, separately, in the U.S. data, and have been assigned estimated rest of world values.

+ North America values involve assigning Canada/Mexico numbers to the U.S.

SOURCE: Francois and Hoekman (1999) and World Bank estimates.

for countries like Indonesia and the Middle East may reflect oil-related and defense activity.

Another source of information used by Francois and Hoekman (1999) is financial data reported by firms listed on stock exchanges. One global database with such information that is often used by financial analysts is Worldscope (1998). This contains financial data on all firms listed on stock exchanges all over the world. While the reported data do not provide enough information to calculate marginal costs -so price-cost margins cannot be calculated-they do allow gross operating margins to be calculated on a 
sector-by-sector basis across countries. ${ }^{5}$ These can be used to infer whether a government's policy stance is more or less restrictive as regards entry and competition. In general, a large number of factors will determine the ability of firms to generate high margins, including market size (number of firms), the business cycle, the state of competition policy enforcement, the substitutability of products, fixed costs, etc. Notwithstanding the impossibility of inferring that high margins are due to high barriers, there should be a correlation between the two across countries for any given sector. Data on operating margins provide some sense of the relative profitability of activities, and therefore, the relative magnitude (restrictiveness) of the barriers to entry/exit that may exist. Of particular interest are differences in average margins across manufacturing and services in different countries. Given that services are less tradable than goods and entry barriers for foreign competitors are generally higher due to the need for establishment (which is costly, if allowed at all), margins can be expected to be higher for services. But variations in the magnitude of the services mark-up across countries may tell us something about the prevalence of barriers.

Average operating margins for all firms in manufacturing and services are reported in Table 4, columns 2 and 3 . The numbers suggest that services margins are significantly higher than manufacturing margins, generally ranging $10-15$ percentage points above those in manufacturing. More interesting is the extent to which the mark-up varies across countries. In only three cases are operating margins similar and/or relatively low (less than 25 percent), suggesting that these are countries where service sectors are quite competitive: Australia, Japan, and Korea. Thailand and China are countries with the highest markup over average margins in manufacturing. Malaysia is another example where service margins are a multiple of those in manufacturing. The markup also is quite large in the United States.

Sectoral data on operating margins also are reported in Table 4, using the (U.S.) Standard Industrial Classification (SIC). The data illustrate again how difficult it is to infer anything about the state of competition, given instances of negative margins in some cases. But, they are again suggestive. For example, margins for hotels and financial services firms tend to be quite high relative to other service sectors in many countries, while wholesale and retail trade, and the consulting sector have margins that are in the 20 percent range or less. If the United States is taken as a competitive benchmark country-which may not be appropriate given high margins in some sectors (such as business services) relative to those, say, in the European Union - it can be observed that in many developing countries margins are significantly higher. One immediate explanation for this may be that in many developing countries there are fewer firms in a sector-frequently there are less than ten, and sometimes there is only one. It is not surprising that in such cases margins can become very high. Examples are recreational services in Taiwan and Thailand; business services in Indonesia; construction in Chile; consulting in China; and hotels in Taiwan, Indonesia, and China. Thus, there is some evidence that policies may be in place in developing countries that restrict competition and allow incumbent firms to garner rents.

Data on operating margins can, in principle, be used in a variety of ways to inform the analysis. One is to use the difference between a benchmark "open" country's average margins and those of the other countries as a measure of the extent to which the latter are more protectionist. This can be a useful way of scaling the level of protection that is assumed to prevail in all the other countries. The difference between manufacturing and service margins also might be used as a scaling factor to estimate the prevailing tariff equivalent. Thus, if the margin for a specific service sector is double that in manufacturing, one might argue that the prevailing tariff equivalent should be at least twice as large as the average tariff on manufacturing. If this approach were to be followed, the end result would not be that different from the tariff equivalents that are obtained by running gravity model regressions - services protection estimates that are no more than double the average merchandise tariff.

An alternative approach to assess the prevalence of barriers to trade in services involves efforts to construct openness indicators for modes of supply, especially FDI, or for specific sectors, using qualitative assessments of the extent to which actual policies raise the costs of entry and/or operation post-entry. ${ }^{6}$ Many of the relevant papers using this approach have been written by a team of Australian academics and staff of the Australian Productivity Commission, and are collected in Findlay and Warren (2000). This

\footnotetext{
${ }^{5}$ Gross operating margins are defined as total sales revenues minus total average costs divided by total average costs

${ }^{6}$ See Warren and Findlay (2000) for an excellent survey of recent work in Australia.
} 
Table 4

\section{Average Gross Operating Margins of Firms Listed on National Stock Exchanges, 1994-96, by Sector (percent)}

\begin{tabular}{lrrrrrrrrrrrr} 
& Mnftg. & $\begin{array}{c}\text { All } \\
\text { Services }\end{array}$ & Rec. & $\begin{array}{c}\text { Business } \\
\text { Services }\end{array}$ & Const. & Consult. & Finance & Health & $\begin{array}{c}\text { Hotels } \\
\text { Retail }\end{array}$ & $\begin{array}{c}\text { Whole- } \\
\text { sale }\end{array}$ & $\begin{array}{c}\text { Trans./ } \\
\text { Util. }\end{array}$ \\
\hline Australia & 15.5 & 16.6 & 17.9 & 13.8 & 15.3 & 7.0 & 41.0 & & 27.3 & 7.9 & 9.1 \\
Canada & 22.6 & 32.9 & 60.1 & 51.7 & 14.4 & 19.2 & 44.5 & 2.3 & 67.8 & 12.0 & 16.0 & 36.5 \\
Chile & 40.8 & 44.0 & & & 68.7 & & 55.2 & & & 21.3 & 27.9 & 46.8 \\
China & 28.1 & 49.5 & & & 45.9 & 67.1 & 34.0 & & 77.5 & 24.4 & 25.5 & 46.9 \\
EU & 23.8 & 31.6 & 42.5 & 32.1 & 19.3 & 22.1 & 51.6 & 22.3 & 23.7 & 23.6 & 19.9 & 32.6 \\
Hong Kong & 12.8 & 18.1 & & 6.5 & 12.9 & 11.5 & 25.4 & & 31.3 & 10.1 & 6.9 & 31.0 \\
Indonesia & 34.3 & 41.3 & & 81.1 & 22.9 & 25.3 & 53.6 & & 68.2 & 26.4 & 24.8 & 45.3 \\
Japan & 26.4 & 28.7 & 28.1 & 31.6 & 14.2 & 28.6 & 40.5 & 40.1 & 27.2 & 32.9 & 15.6 & 20.6 \\
Rep. Korea & 25.7 & 25.8 & & 41.2 & 15.3 & & & & & 26.7 & 14.9 & 31.2 \\
Malaysia & 6.0 & 21.6 & 13.3 & & 18.3 & 14.7 & 28.3 & 24.3 & 38.7 & 11.2 & 10.8 & 30.7 \\
Mexico & 39.3 & 37.2 & 19.6 & & 25.7 & 37.3 & 33.3 & & 49.6 & 28.4 & 25.0 & 51.0 \\
New Zealand & 16.6 & 26.8 & & & 13.8 & & 57.6 & & 26.9 & 6.6 & 19.7 & 35.6 \\
Philippines & 28.6 & 42.3 & 19.9 & & 40.2 & & 53.9 & & 55.8 & 43.9 & 40.3 & 42.3 \\
Singapore & 11.1 & 22.0 & 46.7 & 8.6 & 10.6 & 7.7 & 46.3 & 29.2 & 28.2 & 5.4 & 7.9 & 28.0 \\
Taiwan & 25.1 & 41.3 & 79.9 & 36.3 & 21.6 & 11.1 & 64.8 & & 74.5 & 21.5 & 23.2 & 38.9 \\
Thailand & 27.3 & 52.6 & 85.4 & 35.8 & 38.1 & -8.8 & 60.3 & 40.6 & 55.5 & 44.2 & 25.6 & 56.7 \\
United States & 21.2 & 42.3 & 46.8 & 56.2 & 20.2 & & 56.3 & 37.0 & 48.5 & 34.6 & 27.0 & 43.4 \\
Other Cairns & 31.1 & 39.0 & & & 28.9 & 26.2 & 69.8 & 29.3 & 64.6 & 24.2 & 22.9 & 52.4
\end{tabular}

NOTE: Data are three-year averages. See Francois and Hoekman (1999) for details on the number of firms and calculations.

SOURCE: Francois and Hoekman (1999), drawing on Worldscope (1998).

approach is potentially more relevant than the indirect measures discussed above, as the focus of GATS negotiations is on specific policies and policy disciplines. The basic method is to identify existing policies affecting entry and operations post-entry, assign each a weight, based on interviews of the private sector, and sum across weights to obtain an overall restrictiveness index (Hardin and Holmes, 1997). The results suggest that across Asian-Pacific Economic Cooperation (APEC) countries - which have been the primary focus of attention-communications, financial services, and transport are subject to the greatest barriers to FDI, reflecting the existence of ownership limits or outright bans on foreign ownership (Table 5). The most restrictive countries include Korea, Indonesia, Thailand, and China. As noted above, these are all countries that also report high margins for service sectors. Similar compilations could be done usefully for other regions.
By far, the most attention to date has been devoted to telecom and financial services. Openness indicators for both sectors have been constructed using similar approaches of building indices that weigh policies according to a subjective measure of the extent to which each measure is a binding constraint. A representative example of indices for financial service activities in a number of Asian countries constructed by Claessens and Glaessner (1998) is reported in Table 6. They illustrate that many countries in the region are much more restrictive towards foreign entry than the most liberal economy in the region, Hong Kong. Claessens and Glaessner (1998) also make an assessment of the commitments that were made by countries under the GATS Financial Services Agreement. They conclude that in many instances the prevailing regulatory stance is not more liberal than the country's GATS commitment, and that in some cases, GATS commitments are more liberal 
Table 5

FDI Restrictiveness Indices for Selected APEC Economies and Selected Sectors

\begin{tabular}{|c|c|c|c|c|c|c|c|}
\hline & Business & Communications & Construction & Distribution & Education & Finance & Transport \\
\hline Australia & 18 & 44 & 18 & 18 & 18 & 45 & 20 \\
\hline Canada & 23 & 51 & 20 & 20 & 20 & 38 & 24 \\
\hline China & 36 & 82 & 40 & 28 & 53 & 45 & 46 \\
\hline Hong Kong & 2 & 35 & 0 & 5 & 0 & 23 & 9 \\
\hline Indonesia & 56 & 64 & 53 & 5 & 53 & 55 & 53 \\
\hline Japan & 6 & 35 & 5 & 5 & 20 & 36 & 11 \\
\hline Korea & 57 & 69 & 75 & 63 & 55 & 88 & 57 \\
\hline Malaysia & 32 & 42 & 78 & 8 & 8 & 61 & 12 \\
\hline Mexico & 29 & 74 & 45 & 33 & 45 & 55 & 28 \\
\hline New Zealand & 9 & 43 & 8 & 8 & 8 & 20 & 13 \\
\hline Philippines & 48 & 76 & 48 & 48 & 48 & 95 & 98 \\
\hline Singapore & 26 & 52 & 25 & 25 & 25 & 38 & 25 \\
\hline Thailand & 78 & 84 & 78 & 78 & 78 & 88 & 78 \\
\hline US & 1 & 35 & 0 & 0 & 0 & 20 & 3 \\
\hline
\end{tabular}

NOTE: The higher the score, the greater the degree to which an industry is restricted. Numbers range between 0 and 100 and are indices constructed as a weighted average of ownership limits; equity restrictions on takeovers; screening policies; control restrictions, and operational restrictions.

SOURCE: Adapted from Hardin and Holmes (1997, Appendix A.2); numbers have been rounded up to the nearest integer.

than actual practice. That is, in the latter cases the governments concerned made liberalization (pre) commitments (e.g., Thailand and India on banking; India and Indonesia on securities; and Hong Kong, Indonesia, and the Philippines on insurance). A similar exercise undertaken by Warren (2000) for telecoms is reported in Figure 1. It suggests that China, Korea, and Turkey have the highest restrictions, while the United States, Japan, and Australia have among the lowest. Unfortunately, this ranking cannot be readily compared to the one suggested by the margins, given differences in sectoral aggregation used by authors.

Summing up, business services, consultancy, and distribution do not appear to be among the most protected sectors. The tariff equivalent estimates based on U.S. bilateral trade data, the gross operating margins, and the various measures of openness suggest barriers to competition are higher in transportation, finance, and telecommunications. These are also basic "backbone" inputs that are crucial to the ability of enterprises to compete internationally. With the exception of transportation - which has not been dis- cussed much above-policies towards these sectors appear to be significantly more restrictive in developing countries. Many key transport services are, of course, outside the GATS. Major examples are air and maritime transport and it is well known that in both sectors government restrictions on competition and new entry are frequently severe. ${ }^{7}$ This suggests negotiating attention should focus on financial services, telecoms and transport. ${ }^{8}$

\section{Estimating the Gains from Liberalization: Results of Recent Research}

A number of efforts have been made recently to apply CGE techniques to assess the impact of service sector reform. Two noteworthy attempts explicitly

\footnotetext{
7 See Fink, Mattoo and Neagu (2000), Francois and Wooton (1999) and Mukherjee (1999) for studies on maritime transport.

8 The construction sector is sometimes singled out as an important one for developing countries in terms of potential exports. The data here are not consistent - tariff equivalent estimates based on trade data are relatively high (as expected), but margins and openness indicators suggest that competition in this sector is often relatively vigorous.
} 


\section{Table 6}

Financial Services Openness Indices (1=most closed, $5=$ =most open)

Banking

Securities

Insurance

Capital Controls

\begin{tabular}{|c|c|c|c|c|c|c|c|}
\hline & $\begin{array}{c}\text { GATS } \\
\text { Commitment }\end{array}$ & $\begin{array}{c}\text { Actual } \\
\text { Practice }\end{array}$ & $\begin{array}{c}\text { GATS } \\
\text { Commitment }\end{array}$ & $\begin{array}{c}\text { Actual } \\
\text { Practice }\end{array}$ & $\begin{array}{c}\text { GATS } \\
\text { Commitment }\end{array}$ & $\begin{array}{c}\text { Actual } \\
\text { Practice }\end{array}$ & Practice \\
\hline Hong Kong & 4.20 & 4.75 & 4.00 & 4.40 & 4.40 & 4.00 & 4.80 \\
\hline Indonesia & 3.15 & 3.20 & 3.50 & 3.00 & 3.10 & 2.60 & 3.60 \\
\hline South Korea & 1.10 & 1.70 & 1.70 & 2.10 & 1.20 & 2.60 & 2.65 \\
\hline Malaysia & 2.40 & 2.40 & 2.50 & 2.50 & 2.10 & 2.10 & 2.80 \\
\hline Philippines & 2.80 & 3.35 & 2.40 & 2.40 & 2.90 & 2.80 & 2.45 \\
\hline Singapore & 2.25 & 2.50 & 2.70 & 2.70 & 4.10 & 4.10 & 4.40 \\
\hline Thailand & 2.95 & 2.85 & 2.00 & 2.00 & 2.80 & 2.80 & 4.20 \\
\hline India & 2.70 & 2.25 & 2.50 & 2.10 & 1.00 & 1.00 & 1.50 \\
\hline Average & 2.69 & 2.88 & 2.66 & 2.65 & 2.70 & 2.75 & 3.30 \\
\hline
\end{tabular}

allow for FDI in services. This is crucial, given the importance of this mode of supply to contest service markets. Dee and Hanslow (1999) use the telecom and financial (banking) services openness indices to estimate the impact of barriers to trade in services using a CGE model. One innovation here is to explicitly allow not only for entry through FDI, but also to distinguish between entry and operating restrictions. According to their estimates, barriers to establishment (entry via FDI) are generally much higher than restrictions on ongoing operations of foreign affiliates. Thus, barriers to entry, in the form of implicit taxes on foreign capital, are the primary source of restriction in many developing Asian economies. They conclude that the global welfare effect of services liberalization is roughly the same order of magnitude as that associated with full liberalization of barriers to trade in merchandise (agriculture and manufactures). However, the impact of these two liberalization scenarios differs significantly across countries. For economies such as China, Hong Kong, and Indonesia the gains from services liberalization are a multiple of the gains associated with goods liberalization; while the converse is true for countries such as New Zealand, Japan, Korea, Singapore, Taiwan, the European Union, and the United States. China alone would capture two-thirds of the global gain from services liberalization; the European Union and the United States would lose. In large part, this reflects induced changes in the pattern of FDI stocks and an associated loss in rents to the main providers of FDI. Because no information is available on the prevailing level and distribution of rents generated by status-quo policies, these results must be taken as indicative only. However, they illustrate the importance of undertaking empirical work in this area. ${ }^{9}$

Brown and Stern (1999) use a three-sector multicountry global CGE model to assess the impact of liberalization of services trade and FDI. Firms are taken to be monopolistically competitive, with each firm producing a set of products that are differentiated both by the original $R \& D$ undertaken at headquarters that defines the "basic" product, and by the final location of production. Firms locate production for export or for local consumption depending on

\footnotetext{
${ }^{9}$ Considering whether regulatory barriers generate rents is an important issue that tends to be neglected in numerical modeling work. The greater the extent to which regulatory and administrative practices give rise to resource costs (frictional or transactions costs), the greater the welfare improvement that may result from reform. Hoekman and Konan (1999) use a CGE model of Egypt to assess the orders of magnitude that may be involved in eliminating service-sector inefficiencies. They conclude that Egyptian GDP might expand by some 10 percent of its current GDP if policies are cost-raising.
} 
the type of barriers restraining the conduct of multinationals. These barriers are assumed to take two forms: (i) an ad valorem tax on local capital installed; and (ii) foreign affiliate firms may face a policyinduced fixed cost of production for local operations. Free entry is assumed, ensuring that profits are zero. Brown and Stern use the markup data reported in Francois and Hoekman (1999) as a measure of the barriers that exist to entry (establishment) by foreign firms. Their results reveal that, assuming a fixed global capital stock that is perfectly mobile, the welfare impacts from global liberalization may be huge, with some countries registering increases of up to 30 percent of GDP, and others suffering losses of almost equivalent magnitude. The sign and magnitude of induced welfare changes largely reflect whether a country attracts capital (FDI). If the constant global capital stock assumption is abandoned and allowance is made for an induced increase in the capital stock - which can be expected given a rise in the return to capital - the dispersion in outcomes across countries falls substantially, and almost all countries experience an expansion in output and welfare. Welfare numbers are huge, ranging from 15-40 percent for many countries.

Robinson, Wang, and Martin (1999), and Chadha (1999) use "guesstimates" of the relative restrictiveness of services policies as revealed by the comprehensiveness of their GATS commitments compiled by Hoekman (1996) as inputs into CGE analyses. Robinson et al. (1999) conclude that liberalization of cross-border trade in services-FDI is ignored-can have significant positive effects, especially if account is taken of dynamic effects (the increases in total factor productivity (TFP) due to technology transfer via expansion of trade in capital goods and intermediate inputs). They find that the welfare gain for the world from a 50 percent cut in service protection is five times larger than full elimination of merchandise trade barriers. This reflects the importance of transport services and backward and forward linkages between and among services and goods sectors. Chadha (1999) uses a multicountry CGE model that separates out India, and runs simulations making different assumptions regarding prevailing market structures in agriculture, manufacturing, and services. He concludes that Indian welfare would expand by 0.7 to 1.4 percent of GDP following a 25 percent global reduction in the assumed vector of services protection. Other South Asian countries and Southeast Asian countries are expected to register gains equivalent to 3 percent of GDP. These numbers are quite large relative to

\section{Figure 1}

\section{Restrictiveness Indices to Trade in Telecommunications Services \\ Top 20 Services Trading Nations, 1997}

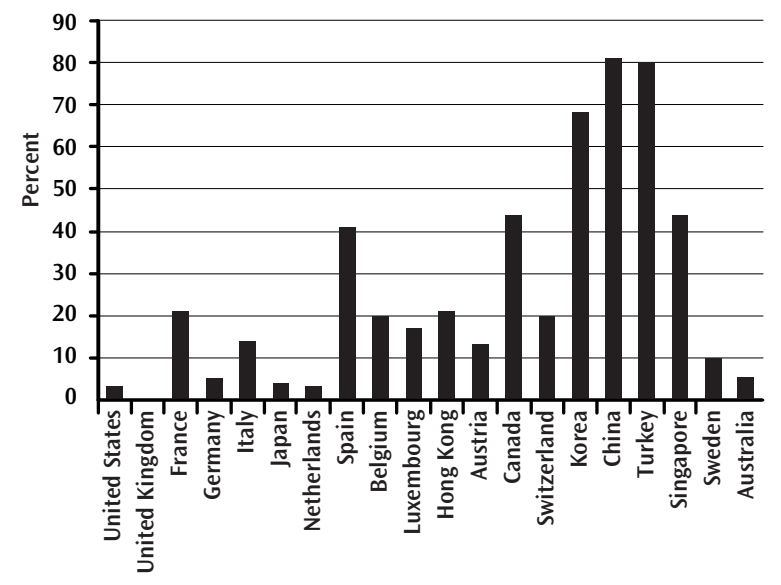

NOTE: The higher the score, the greater the degree to which an industry is restricted. The maximum score is $100 \%$

SOURCE: Warren (2000).

what is usually found using similar types of models to assess the impact of merchandise trade liberalization.

Summing up, although the data situation is not very good, quite a bit can be done by analysts to quantify the relative magnitude of prevailing barriers and the magnitude and distribution of the gains of increasing competition on services markets. The challenge is to do it, and build on recent and ongoing research. The research clearly suggests that potential gains from liberalization may be very large. ${ }^{10}$ While this work is important and useful, the state of the data on barriers is such that, in the near term, policymakers will have to continue to rely primarily on rules of thumb in determining negotiating priorities. Basic economics suggests that the focus of attention should be on the contestability of markets (artificial entry restrictions) and defining clusters of activities that are interdependent. There is a growing literature that provides rules of thumb or criteria to identify whether an acceptable level of competition exists in a given service industry at a given period of time. For

\footnotetext{
10 This conclusion is bolstered by recent theoretical work, which has identified a number of additional linkages between goods and services markets that expand the gains from liberalization. See, e.g., Deardorff (1999), Francois and Wooton (1999) and Markusen, Rutherford and Tarr (1999).
} 
instance, air routes with less than three operating airlines are unlikely to be under intensive competition, and large gains from regulatory reforms can be expected (Morrison and Winston, 1997). In the case of multimodal competition (such as between trains and airlines), price comparisons between similar air routes with and without multimodal competition can be a good proxy for assessing the capacity of regulatory reforms to deliver the benefits of increased competition. This type of work also requires research and analysis, but is more straightforward to undertake for government agencies. But, here again, the challenge is to do it. Without such efforts, appropriate negotiating priorities cannot be determined. In short, benefiting from GATS negotiations requires a large amount of preparatory work, something that many countries have not been engaged in. As a result, the process of negotiations is likely to be driven more by well-organized export interests in industrialized countries, as was the case in the Uruguay Round. This is not necessarily bad, but it is unlikely to maximize the potential gains from negotiation.

\section{WHAT TO NEGOTIATE?}

The next set of negotiations on services are likely to focus primarily on (i) expanding the coverage of specific commitments; and (ii) improving multilateral rules. ${ }^{11}$ However, it can be argued that priority should also be given to increasing information on prevailing policies.

\section{Towards Full Transparency}

Given the weakness of the available data on barriers, governments must rely on their private sectors to inform them on what they think matters, and on their economists to tell them what types (clusters) of regulatory reforms are in the national interest. A key weakness of the GATS is that it does not force members to "come clean" regarding the measures that are used to restrict the ability of foreigners to contest domestic service markets. The positive list approach used to schedule commitments often has been criticized for this reason, although it can be defended on the basis that a negative list would have been too cumbersome to make operational at the time of the Uruguay Round. ${ }^{12}$ It is very unlikely that negotiators will be willing to reopen the issue of scheduling commitments, and efforts to achieve this are likely to be counterproductive. But the Australian proposal, made at the December 1996 Singapore WTO Ministe- rial meeting, to engage in a negative list reporting exercise for transparency purposes deserves to be reconsidered. What is required is that the prevailing policies, which discriminate against foreign competition, are identified and that this information be made publicly available.

Even if it can be agreed that governments will engage in a transparency exercise and agree to notify their existing policies, GATT and WTO experience suggests there will be substantial non-compliance. ${ }^{13}$ An alternative option is to give the transparency task to a specialized body. One such entity was created during the Uruguay Round - the Trade Policy Review Mechanism (TPRM). ${ }^{14}$ Agreement could be sought that as part of each country review, the TPRM make a comprehensive survey of the prevailing status quo on services-related policies in each WTO memberif necessary, drawing upon outside expertise to assist in the preparation of the first review for each country. This will undoubtedly require additional resources, which will need to be made available. This survey should not just cover measures in legal terms, but also the key aspects that matter economically for specific activities-such as interconnect rates, licensing fees, accounting rates-and report information on market structures, size distribution of firms, turnover (entry, exit), etc. ${ }^{15}$ An alternative is to rely much more on the private sector to provide information on barriers and enhance the incentives for private parties to use WTO dispute settlement mechanisms (Hoekman and Mavroidis, 2000).

\section{Expanding the Coverage of the GATS}

After the Uruguay Round was concluded in 1994, it rapidly became clear that the sectoral coverage of the specific commitments on national treatment and

\footnotetext{
11 For much more comprehensive discussions of what could and should be done to improve the GATS, see Feketekuty (1998; 2000), Mattoo (2000), and Snape (1998). This section builds on Hoekman (2000).

${ }^{12}$ Defenders of the negative list respond that transition periods could have been defined during which countries could determine what they wanted to schedule as exceptions, complemented with technical assistance to help undertake the required policy and legislative review exercise.

${ }^{13}$ As is the case, e.g., with the notification obligation to report the outcome of bilateral settlements in disputes notified to the WTO-see Hoekman and Mavroidis (2000).

${ }^{14}$ See Francois (1999) for a critical discussion of the TPRM.

${ }^{15}$ See Djankov and Hoekman (1998) for the types of data that might be compiled and analyzed.
} 
market access was rather limited for many countries. Also, countries that had scheduled sectors frequently listed a variety of measures that allowed them to continue to restrict or limit either market access or national treatment. By one measure, high-income countries only made commitments on about half of all services, of which only one-half involved commitments of "free access." Thus, there were no restrictions on market access or national treatment for only 25 percent of all service activities. Developing countries made even fewer commitments. In the case of major developing countries, on average, "free access" commitments were made for only 15 percent of the service sector (Hoekman, 1996). Subsequently, successful negotiations expanded the coverage of specific commitments for basic telecoms and financial services. ${ }^{16}$

The stylized facts are well known: The coverage of specific commitments is limited for many countries, and in many cases the commitments are more restrictive than the status quo policies that are actually applied. That is, many governments have refrained from binding the status quo. Examples pertaining to financial services were mentioned above, where countries scheduled foreign ownership limits that are more restrictive than those currently enforced, thereby providing the option to force firms to reduce equity stakes in the future. One interesting feature that has been remarked upon is that more commitments have tended to be made with respect to FDI ("mode 3") than cross-border trade ("mode 1"), but that a number of countries' commitments are such as to favor infusions of foreign equity into existing firms and limit the ability of entry by new firms. As noted by Mattoo (2000), such protection of incumbents and/or existing market structures is difficult to rationalize and must be carefully monitored, as it can easily result in a transfer of rents to foreign firms rather than a socially desirable increase in competition and lower prices/higher quality output.

One of the challenges confronting negotiators will be to expand the sectoral coverage of specific commitments. A strong case can be made that the GATS should cover all services. There is no rationale for excluding certain sectors or modes of supply from the national-treatment and market-access disciplines. Given that the GATS allows for derogations to both principles, at the very least, comprehensive scheduling will ensure that a government is forced to consider the justification and economic rationale for the policies it maintains that are not in conformity with these principles. One way of moving towards this is to apply a formula approach to expanded coverage in the next round of negotiations, setting minimum coverage targets for GATS members, to be attained by a specified date (which may vary depending on per-capita income level to allow for a transition period). This could include agreement that a specified share of all commitments involve full binding of status quo policies. A more ambitious approach would be to seek agreement on a deadline for full coverage to be reached. It seems unlikely that WTO members will be willing to consider moving from a positive to a negative list approach to scheduling commitments - but there is nothing to prevent individual countries from doing so.

Whatever formula or focal point is established for the negotiations, individual countries should consider going beyond this. In the process, valuable information can be obtained on how different policies affect clusters of activities that are inter-related and interdependent. As noted earlier, it is useful to think and work in terms of clusters of related activities. The current sectoral approach to scheduling makes little economic sense as it ignores complementarities and interdependencies. The problems that can arise are illustrated by the examples of Ecommerce, energy services, and international express services (see Barfield and Groombridge, 1999).

One way to reduce potential inconsistencies is to require one-to-one mappings between commitments relating to modes 1 and 3 ("non-discrimination across modes"). Such modal neutrality is an objective worth pursuing because, as is often emphasized in the literature, trade and investment have increasingly become complementary. It also is frequently noted that it will become increasingly difficult to maintain a clear distinction between trade in goods and trade in services, as technology may give producers the choice of delivering their products in tangible or in disembodied (digitized) form. A priori, it would appear that any multilateral disciplines should apply equally to international transactions regardless of the mode of supply. A case can be made that WTO members may wish to consider developing disciplines that distinguish between trade and investment, with trade in goods or services being subject to a set of common rules, and movement of factors of production being subject to another set of rules. This, in effect, has been the approach taken in the NAFTA, which includes a sepa-

\footnotetext{
${ }^{16}$ See Cowhey and Klimenko (1999) on the telecom agreement; Key (1997) on the financial services agreement.
} 
rate chapter on investment (in goods or services) and is distinct from the rules relating to cross-border trade (in goods and services). Emulating this approach would result in much greater consistency and clarity of the applicable rules and disciplines, but clearly goes much beyond the ambit of the GATS. Within the GATS, setting a focus on modal neutrality can be a useful halfway house.

\section{Improving the Rules}

The primary disciplines embodied in the GATS are most favored nation (MFN), market access and national treatment - the latter two only on a sectormode basis, and subject to exceptions if governments desire to schedule them. A formula approach to expanding sectoral coverage could be complemented by efforts to increase the impact of multilateral disciplines for certain modes of supply. Feketekuty (2000) has argued that national treatment should become a general principle applying to mode 3 (FDI). If combined with greater use of horizontal rules based on pro-competitive principles, this would help make the GATS more transparent and more relevant to investors. Ideally, scheduling of liberalization commitments should shift from the sectoral (specific) to the horizontal (general). This would allow negotiating efforts to center more on developing disciplines that make sense from a long-term growth and economic development perspective. In general, these are likely to focus on safeguarding the contestability of markets, while maintaining national sovereignty to regulate activities to attain health, safety, prudential and related objectives. In this perspective, it would be useful to consider generalizing the appropriate parts of the so-called "Reference Paper" in telecoms to make it a horizontal set of disciplines to be incorporated into the GATS as such. The Reference Paper includes concepts such as "affecting the terms of participation" and "essential facilities" that could usefully be extended to all services, even those without any background of monopoly or public ownership or control.

A strict policy of MFN also is desirable. In the Uruguay Round, countries were permitted to schedule MFN exemptions, in part reflecting a concern by regulators that MFN might impede their ability to intervene, or a desire by governments to discriminate on a sectoral basis (e.g., culture). If deemed necessary, existing provisions in the GATS that give regulators the ability to pursue actions that discriminate across firms (to achieve regulatory objectives) could be strengthened as a quid pro quo for adoption of an unconditional, general MFN rule (although the GATS already is quite explicit in providing a carve out for regulatory purposes). Mandatory MFN also should apply in the area of standards and mutual recognition, with non-recognition being made easier to contest through dispute settlement. However, it must be recognized that multilateral cooperation may be required to mitigate the competition-reducing effect of domestic regulations, especially in the area of mandatory standards-for product safety, professional certification, and prudential regulation. This is perhaps the major area where future efforts at rulemaking should be focused, not least because it is one where many countries are embarking on initiatives to achieve "deeper integration" in the context of regional agreements.

Finally, what about the "outstanding" issues that were left open after the Uruguay Round and on which little progress has been made since then: subsidies, procurement, and safeguards? Arguably, there is little need for GATS-specific disciplines in any of these areas. Procurement is a general issue, so that any disciplines should cover goods and services. What really matters for foreign firms is to have access to procurement markets, and frequently this can only be achieved if they have a commercial presence in a country. In economic terms, what matters is not so much policies of discrimination, but the ability of foreign firms to establish. Thus, if the coverage of the GATS is expanded and the suggestion of Feketekuty is taken up-national treatment for mode 3-there is little need for stand-alone services procurement disciplines (Evenett and Hoekman, 2000).

Although multilateral disciplines on subsidies might help avoid mutually destructive policies from the viewpoint of developing countries-for example, seeking to attract FDI via the use of incentives-it is not clear that there is a significant problem of negative spillovers (Langhammer, 1999). Subsidies are the source of important distortions in OECD markets for some services such as transport. It is very unlikely that the GATS will be able to do much to restrain governments. Many studies conclude that fiscal incentives have little if any impact on the location decisions of foreign investors. Even if one does not accept this conclusion, competition (non-cooperation) could be welfare improving for the world as a whole (Hoekman and Saggi, 1999). Noteworthy is that the stillborn Multilateral Agreement on Investment (MAI) excluded incentives, so one can infer that OECD countries are not in the "market for discipline." To be effective in 
disciplining the use of firm-specific fiscal incentives, subsidy disciplines will have to be quite comprehensive to ensure that countries cannot side-step them through the use of alternative policies. The GATT/ WTO negotiating and implementation history illustrates that agreement on subsidy and related disciplines is difficult to obtain, and that any disciplines may easily be circumvented. Even the European Union-which goes much further than the WTO in this area-has encountered recurrent difficulties associated with government policies intended to attract FDI and enforce its restrictions on the use of State aids. NAFTA does not even try to tackle this issue. All in all, Snape's (1987) prescription for "subsidy freedom" seems the best way to proceed in this area. In any event, the same conclusion arises as for procurement-any disciplines should be general, not sector-specific.

It also can be argued that there is no need for safeguards instruments. Insofar as governments want to "backslide," they can make recourse to renegotiation modalities that already are built into the GATS. GATT-type safeguards (emergency protection) are difficult to rationalize in the services context because in many cases it will require taking action against foreign firms that have established a commercial presence. Why a government would want to do this is unclear, as it will deter, not attract, FDI. If it is to be considered, it would most likely have to exempt mode 3. But, then it must be considered that safeguards (or their threat) can easily act as an investment incentive, and result in resource allocation distortions. There is, however, a potentially compelling counter argument. A case could be made that the extremely limited nature of liberalization commitments to date is in part due to the non-existence of safeguards instruments. This is most likely to apply to mode 4-temporary movement of service providers. As this mode of supply is of major interest to developing countries and one on which almost all countries maintain stringent restrictions, one could envisage a safeguard instrument that is limited to mode 4 liberalization commitments, and is explicitly aimed at providing OECD country governments with an insurance mechanism that can be invoked if liberalization has unexpected detrimental impacts on their societies.

\section{CONCLUDING REMARKS}

Many observers have noted that the GATS is an imperfect instrument (e.g., Hoekman, 1996; Snape,
1998). Notwithstanding the deficiencies, it can be used as a commitment and signaling device by governments that have decided that regulatory reforms are in the national interest. Specific commitments can be made for all modes of supply, including FDI, and governments that have decided to open access to services markets to foreign providers should pursue the option of locking-in policy reforms as much as possible through the existing GATS mechanisms. Future efforts to expand GATS disciplines should center on expanding the sectoral coverage of the agreement and simplifying and strengthening the rules along the lines discussed previously.

There are undoubtedly gains from enhancing competition in service markets. Recent theoretical and numerical research, some of which was discussed earlier, clearly reveal that the gains can be quite large. To a large extent these payoffs can be realized through autonomous reform efforts, and many countries have been pursuing reforms more vigorously in the last decade. The major challenge confronting negotiators in the next round may be to create incentives for developing countries to expand their commitments under the GATS. Given ongoing efforts in many countries to adopt a more market and pro-competitive policy stance, the focus of attention can be expected to center on increasing the extent to which both the status quo and future (autonomous) reforms are scheduled in the GATS. This depends importantly on the value that is placed on such scheduling by reforming economies themselves and the "demandeur" countries that want governments to lock-in reforms in the GATS. Arguments by economists that the WTO can be used as a valuable credibility-bolstering device have proven to be less than compelling to policymakers. Thus, the mercantilist logic of multilateral negotiations is likely to require that industrialized countries improve export market access opportunities for developing countries. Absent such a quid pro quo it may prove difficult to greatly expand the coverage of the GATS in areas where the economic payoffs are highestsectors where entry restrictions are most severe or the perceived probability of policy reversal is high.

There is a great need for more and better surveillance and monitoring of the prevalence and effects of policies that imply discrimination against foreign competitors in service sectors. Bolstering the transparency and information collection and dissemination functions of the WTO Secretariat would help improve matters. Although much has been done since the creation of the WTO to increase access to official 
documents, less has been achieved in the area of data and statistics. WTO databases of trade and tariff information are not publicly accessible. Trade policy reviews are not posted on the web, nor are the underlying data that are used in the reports. Even if agreement is reached among WTO members to provide comprehensive reports on their prevailing services policy regimes for transparency purposes, to be most useful this data should be put into the public domain. Requiring the WTO Secretariat to compile and distribute data that is reported to it, both policyoriented and statistics, and making this information available free of charge through the Web, can be defended as a public good that the institution has a mandate to provide.

\section{REFERENCES}

Barfield, Claude and Mark Groombridge. "Electronic Commerce and the GATS 2000 Round.” Unpublished manuscript, American Enterprise Institute, 1999.

Brown, Drusilla and Robert Stern. "Measurement and Modeling of the Economic Effects of Trade and Investment Barriers in Services," World Services Congress Paper, November 1999.

Chadha, Rajesh. "GATS and Developing Countries: A Case Study of India,” World Services Congress Paper, November 1999.

Claessens, Stijn and Tom Glaessner. "Internationalization of Financial Services in Asia." Unpublished manuscript, World Bank, 1998.

Cowhey, Peter and Mikhail Klimenko. "The WTO Agreement and Telecommunication Policy Reforms," WTO 2000 Capacity Building Project Background Paper, World Bank, 1999.

Deardorff, Alan. "International Provision of Trade Services; Trade and Fragmentation," mimeo, University of Michigan, 1999.

Dee, Philippa and Kevin Hanslow. "Multilateral Liberalization of Services Trade," World Services Congress Paper, 1999.

Djankov, Simeon and Bernard Hoekman. "Conditions of Competition and Multilateral Surveillance," The World Economy (November 1998), pp. 1109-28.

Evenett, Simon and Bernard Hoekman. "Government Procurement of Services and Multilateral Disciplines," GATS 2000: New Directions in Services Trade Liberalization, Pierre Sauve and Robert Stern, eds.,Washington DC: Brookings Institution, 2000.

Feketekuty, Geza. "Setting the Agenda for Services 2000: The Next Round of Negotiations on Trade in Services," Launching New Global Trade Talks: An Action Agenda, Jeffrey Schott, ed., Washington DC: Institute for International Economics, 1998, pp. 91-110.
"Assessing the WTO General Agreement on Trade in Services and Improving the GATS Architecture" GATS 2000: New Directions in Services Trade Liberalization, Pierre Sauve and Robert Stern, eds., Washington DC: Brookings Institution, 2000.

Findlay, Christopher, and Tony Warren, eds. Impediments to Trade in Services: Measurement and Policy Implications, Routledge, Sydney, forthcoming 2000.

Francois, Joseph. "Maximizing the Benefits of the Trade Policy Review Mechanism for Developing Countries," WTO 2000 Capacity Building Project Background Paper, World Bank, February 1999.

Fink, Carsten, Aaditya Mattoo and I.C. Neagu, “Trade in International Maritime Services: How Much Does Policy Matter?" World Bank, mimeo, 2000. , and Bernard Hoekman. "Market Access in the Services Sectors.” Unpublished Manuscript, 1999. and Ian Wooton. "Trade in International Transport Services: The Role of Competition.” Unpublished Manuscript, Tinbergen Institute, Erasmus University Rotterdam, 1999.

Hardin, Alexis and Leanne Holmes. "Services Trade and Foreign Direct Investment," Industry Commission Staff Research Paper, Production Commission Australian, AGPS, Canberra, November 1997.

Hoekman, Bernard. "Assessing the General Agreement on Trade in Services," The Uruguay Round and the Developing Countries, Will Martin and L. Alan Winters, eds., Cambridge University Press, 1996, pp. 88-124.

"Toward a More Balanced and Comprehensive Services Agreement," Institute for International Economics, mimeo, 2000.

, and Carlos A. Primo Braga. "Protection and Trade in Services: A Survey." Open Economies Review (July 1997), pp. 285-308.

, and Denise Konan. "Deep Integration, Nondiscrimination and Euro-Mediterranean Free Trade," Center for Economic Policy Research Discussion paper 2095, March 1999.

, and Petros C. Mavroidis. "WTO Dispute Settlement, Transparency and Surveillance," The World Economy (April 2000), pp. 527-42.

, and Patrick Messerlin. "Liberalizing Trade in Services: Reciprocal Negotiations and Regulatory Reform," GATS 2000: New Directions in Services Trade Liberalization, Pierre Sauve and Robert Stern, eds., Washington DC: Brookings Institution, 2000. and Kamal Saggi. "Multilateral Disciplines for Investment-Related Policies?” Policy Research Working Paper 2138, World Bank, June 1999.

Karsenty, Guy. "Just How Big Are the Stakes?," GATS 2000: New Directions in Services Trade Liberalization, Pierre Sauve and Robert Stern, eds., Washington DC: Brookings Institution, 2000. 
Key, Sydney. "Financial Services in the Uruguay Round and the WTO." Group of Thirty Occasional Paper 54, Washington DC, 1997.

Langhammer, Rolf. "The WTO and the Millennium Round: Between Standstill and Leapfrog," Kiel Discussion Paper 352, August 1999.

Markusen, Jim. Thomas Rutherford, and David Tarr. "Foreign Direct Investment in Services and the Domestic Market for Expertise," Unpublished Manuscript, 1999.

Mattoo, Aaditya. "Developing Countries in the New Round of GATS Negotiations: Towards a Pro-active Role," The World Economy (April 2000), pp. 471-90.

Morrison, Steven and Clifford Winston. "The Fare Skies: Air Transportation and Middle America," The Brookings Review (Fall 1997), pp. 42-45.

Mukherjee, Neela. "Multilateral Negotiations and Trade Barriers in Service Trade: A Case Study of U.S. Shipping Services," World Services Congress Paper, 1999.

Productivity Commission. International Benchmarking of Australian Telecommunications Services, Melbourne: AusInfo, 1999.

Robinson, Sherman, Zhi Wang, and Will Martin. "Capturing the Implications of Services Trade Liberalization," Unpublished manuscript, World Bank, 1999.

Snape, Richard. "The Importance of Frontier Barriers," in Protection and Competition in International Trade, Henryk Kierzkowski, ed., Blackwell, 1987, pp. 215-32.

"Reaching Effective Agreements Covering

Services," in The WTO as an International Organization, Anne O. Krueger, ed., University of Chicago Press, 1998, pp. 279-93.

United Nations Conference on Trade and Development, and World Bank. Liberalizing International Transactions in Services: A Handbook, United Nations, 1994.

Warren, Tony. "The Application of the Frequency Approach to Trade in Telecommunications Services," in Impediments to Trade in Services: Measurement and Policy Implications, C. Findlay and T. Warren, eds., Routledge, Sydney, 2000.

, and Chris Findlay. "How Significant are the Barriers? Measuring Impediments to Trade in Services", GATS 2000: New Directions in Services Trade Liberalization, Pierre Sauve and Robert Stern, eds., Washington DC: Brookings Institution, 2000.

Whichard, Obie. "Measurement, Classification and Reporting of Services Activities: An International Perspective," WTO 2000 Capacity Building Project Background Paper, World Bank, 1999.

Worldscope. "Corporate Financial and Ownership Indicators," Bethesda, Maryland, 1998.

World Bank. Trade Blocs and Beyond: Political Dreams and Practical Decisions. Washington DC: World Bank, 2000. 
RE V IE W

48 julv/august 2000 